
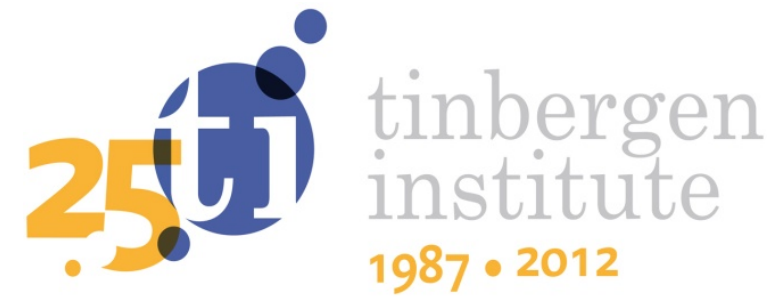

\title{
Business Cycle Fluctuations and Private Savings in OECD Countries: A Panel Data Analysis
}

\author{
Yvonne Adema* \\ Lorenzo Pozzi
}


Tinbergen Institute is the graduate school and research institute in economics of Erasmus University Rotterdam, the University of Amsterdam and VU University Amsterdam.

More TI discussion papers can be downloaded at http://www.tinbergen.nl

Tinbergen Institute has two locations:

Tinbergen Institute Amsterdam

Gustav Mahlerplein 117

1082 MS Amsterdam

The Netherlands

Tel.: +31(0)205251600

Tinbergen Institute Rotterdam

Burg. Oudlaan 50

3062 PA Rotterdam

The Netherlands

Tel.: +31(0)10 4088900

Fax: $+31(0) 104089031$

Duisenberg school of finance is a collaboration of the Dutch financial sector and universities, with the ambition to support innovative research and offer top quality academic education in core areas of finance.

DSF research papers can be downloaded at: http://www.dsf.nl/

Duisenberg school of finance

Gustav Mahlerplein 117

1082 MS Amsterdam

The Netherlands

Tel.: +31(0)20 5258579 


\title{
Business cycle fluctuations and private savings in OECD countries: a panel data analysis
}

\author{
Yvonne Adema*1 and Lorenzo Pozzi ${ }^{2}$ \\ ${ }^{1}$ Department of Economics, Erasmus University Rotterdam, Tinbergen Institute $\mathcal{G}$ Netspar \\ ${ }^{2}$ Department of Economics, Erasmus University Rotterdam $\&$ Tinbergen Institute
}

December 10, 2012

\begin{abstract}
We investigate the cyclicality of the private savings to GDP ratio for a panel of 19 OECD countries over the period 1971-2009. We find robust evidence that the private savings ratio is countercyclical. Three theories unambiguously predict a higher private savings ratio during recessions: a Ricardian offset effect, the presence of credit constraints, and precautionary savings. We find evidence only for the latter theory. Our estimations take into account a large number of econometric complications: persistence in the savings ratio, endogeneity of the regressors, crosscountry parameter heterogeneity, cross-sectional dependence, stationarity issues, omitted variables, and instrument strength.
\end{abstract}

JEL Classification: C23, E21, E32

Keywords: Private Savings, Business Cycles, Ricardian offset, Credit Constraints, Precautionary Savings, Dynamic Panel, Cross-Sectional Dependence

\footnotetext{
${ }^{*}$ Corresponding author: Department of Economics, P.O. Box 1738, 3000 DR Rotterdam, the Netherlands. Email: adema@ese.eur.nl. Website: http://people.few.eur.nl/adema.
} 


\section{Introduction}

The financial crisis of 2007-2008 caused the longest recession in the US since World War II; according to the NBER the recession lasted from December 2007 to June 2009. Not only the US experienced a long lasting recession, basically the whole developed world underwent a severe slowdown in economic activity. The fiscal stimulus packages implemented by governments during this period were enormous. Although these measures probably dampened the recession to some extent, consumer confidence stayed low and the fiscal stimuli were not very effective in terms of boosting consumer spending. The effectiveness of fiscal policy during recessions crucially depends on how the ratio of private consumption or private savings to GDP responds to the business cycle.

In this paper, we investigate the cyclicality of the private savings to GDP ratio in OECD countries. Surprisingly, the literature on this topic is scarce. This is unfortunate because the economic implications of either a procyclical or a countercyclical private savings ratio are very different. With respect to business cycles, a procyclical savings ratio implies that business cycle fluctuations are dampened by changes in the private savings ratio. In that case a recession, for instance, lowers the private savings ratio and increases the consumption to GDP ratio and therefore boosts aggregate demand. The increased fiscal multiplier furthermore improves the effectiveness of fiscal policy actions to fight the recession. A countercyclical private savings ratio, on the other hand, implies that business cycle fluctuations are amplified by changes in the private savings ratio. Here, a recession increases the private savings ratio and decreases the consumption to GDP ratio and therefore lowers aggregate demand. And the lower fiscal multiplier reduces 
the effectiveness of fiscal policy actions to fight the recession. With respect to economic growth, a procyclical savings ratio implies that during downturns wealth and capital accumulation fall so that recessions have a negative long-run impact on economic growth, whilst a countercyclical savings ratio implies that recessions can increase wealth and capital accumulation and long-run economic growth.

Different economic theories predict contrasting effects of the business cycle on the private savings ratio (see Carroll and Summers (1987), Carroll (1992)). According to the consumption smoothing hypothesis which is implied by life cycle/permanent income theories of consumption, the private savings ratio is procyclical. During downturns, income is temporarily lower and people smooth consumption so that consumption as a fraction of income rises and saving as a fraction of income falls. During upturns, exactly the opposite holds; people save relatively more as they have a temporarily higher income. Buffer stock models that allow for precautionary savings motives, on the other hand, suggest that the private savings ratio is countercyclical. During recessions, there is more labor income uncertainty (i.e., a higher risk of unemployment) so that a larger fraction of income is saved, and vice versa during upturns.

Although not much is known about the cyclicality of the private savings ratio, there is nonetheless an impressive literature that deals with the determinants of the private savings ratio (see e.g., Edwards, 1996; Masson et al., 1998; Loayza et al., 2000). Papers in this literature typically first give an overview of the determinants of private saving rates based on the theoretical literature. They then use indicators of these theoretical determinants and estimate reduced-form linear equations to test the main determinants of private saving rates empirically. In almost all studies the determinants included in the 
savings regressions are the growth rate of per capita real GDP, the inflation rate, the real interest rate, the credit ratio, the government budget surplus, the size of the social welfare system and the dependency ratio. ${ }^{1}$ Although these studies focus on the determinants of the private savings ratio, no study analyzes the effects of the business cycle on the private savings ratio. Of course, the business cycle affects the private savings ratio through these determinants. While some determinants predict a procyclical savings ratio - e.g., real GDP growth and inflation which are procyclical variables with a documented positive impact on the private savings ratio - and other determinants predict a countercyclical private savings ratio - e.g., the government savings ratio which is itself procylical and is generally acknowledged to have a negative impact on the private savings ratio - the overall cyclicality of the private savings ratio is not known. Albeit Lane and Tornell (1998) investigate the cyclicality of the domestic or national savings rate and document that domestic savings rates in the OECD are procyclical, this evidence cannot tell us much about the cyclicality of the private savings ratio in OECD countries. The reason is that the domestic savings to GDP ratio depends both on the private and on the government savings to GDP ratio, of which the latter is known to be strongly procyclical.

To the best of our knowledge, no systematic and thorough investigation has been conducted that can shed light on whether the private savings ratio in OECD countries is procyclical, countercyclical, or acyclical. The aim of our study is to fill this gap in the literature. To this end, we investigate the cyclicality of the private savings ratio in a panel of 19 OECD countries using annual data over the period 1971-2009.

In the first part of the paper, we determine whether the private savings ratio in

\footnotetext{
${ }^{1}$ We refer to Loayza et al. (2000) for an excellent overview of the literature on the determinants of private saving rates.
} 
OECD countries is on average pro-, counter- or acyclical by regressing the private savings ratio on the lagged private savings ratio and on a business cycle indicator. We use both unemployment-based and GDP-based business cycle measures. We find robust evidence that the private savings ratio is countercyclical, i.e., it increases during recessions. To the best of our knowledge, this result has not been reported elsewhere.

In the second part of the paper, we put forward three theories that unambiguously predict a higher private savings ratio during recessions: a Ricardian offset effect (see e.g., Lopez et al. (2000), de Mello et al. (2004)), the presence of credit constraints (see e.g., Jappelli and Pagano (1994)), and the existence of a precautionary savings motive induced by labor income uncertainty (see e.g., Carroll (1992)). While these theories have been tested before in the empirical literature on the determinants of the private savings ratio, our paper reemphasizes their relevance to explain the countercyclicality of the private savings ratio documented in the first part of the paper. We then test the theories by regressing the private savings ratio on the lagged private savings ratio and on explanatory variables that reflect these three theories, i.e., the (cyclical) government savings to GDP ratio, the (cyclical) private sector credit to GDP ratio, and the (cyclical) unemployment rate which is used here as a proxy for labor income uncertainty.

Methodologically, we estimate the dynamic private savings regressions put forward in the paper using a macro panel data approach (i.e., 19 countries, 39 years). A panel data approach is particularly suited to determine the cyclicality of the private savings ratio because the number of recessions in a given country over time is relatively low. By using a panel of countries, the number of recessionary episodes in the sample increases, so that more reliable and more general conclusions with respect to cyclicality can be obtained. 
We make full use of the panel structure of the data. First, we estimate country-specific coefficients which are then combined using the mean group (MG) estimator to obtain estimates for the average effects. This avoids obtaining biased and inconsistent parameter estimates when falsely assuming that the regression slope parameters are identical across countries. We refer to Pesaran and Smith (1995) for a general discussion on this issue and to Haque et al. (1999) for a specific discussion on this issue for savings regressions. Differences across countries of the impact of the determinants of private savings (like the business cycle) can for instance be due to cross-country differences in financial systems, government policies and institutions, and demographics. Second, we allow for crosssectional dependence in the data. Recently, the panel literature has emphasized the potential presence in panel regression errors of omitted unobserved common variables that have differential impacts on the individual units (see Pesaran (2006)). Especially when studying macroeconomic data, such unobserved global variables or shocks are likely to be the rule rather than the exception (see e.g., Bond et al. (2010)). In the context of aggregate private savings, common factors may for instance be induced by financial liberalization and, of particular relevance to our application, by common business cycle components. To take this cross-sectional dependence into account, we use the common correlated effects (CCE) methodology suggested by Pesaran (2006). The basic idea behind CCE estimation is to capture the unobserved common factors by including cross-sectional averages of the dependent and of the explanatory variables as additional regressors in the model. We use the mean group (CCEMG) variant to allow for possible parameter heterogeneity. We also use generalized method of moments (GMM) versions of the MG and CCEMG estimators to account for endogeneity of the explanatory variables (see Everaert and Pozzi (2012)). We 
further tackle potential problems stemming from non-stationarity, instrument weakness when using the GMM estimators, and omitted variables.

The paper is structured as follows. Section 2 presents evidence on the cyclicality of the private savings ratio in OECD countries, i.e., we show that the private savings ratio is countercyclical. Section 3 then discusses and tests three theories that can explain a countercyclical private savings ratio: a Ricardian offset effect, the presence of credit constraints, and precautionary saving motives. Section 4 concludes.

\section{Cyclicality of the private savings ratio: evidence}

This section investigates how the private savings to GDP ratio depends on the business cycle, i.e., whether the private savings ratio is pro- or countercyclical.

\subsection{Empirical specification}

To estimate the cyclicality of the private savings to GDP ratio for a sample of $N$ countries, we use the following empirical specification

$$
s_{i t}=\eta_{i}+\alpha_{i} s_{i t-1}+\beta_{i} b c_{i t}+\varepsilon_{i t} \quad i=1,2, \ldots, N, \quad t=2, \ldots, T,
$$

where $s_{i t}=\frac{S_{i t}^{P}}{Y_{i t}}$ denotes private savings $S_{i t}^{P}$ expressed as a fraction of GDP $Y_{i t}$ (both expressed in real terms) and $b c_{i t}$ is a business cycle indicator. We estimate eq.(1) separately for five business cycle indicators. These indicators are the unemployment rate $U_{i t}$, the change in the unemployment rate $\Delta U_{i t}$, the GDP growth rate $\Delta \ln Y_{i t}$, the output gap ratio $\frac{Y_{i t}-\bar{Y}_{i t}}{\bar{Y}_{i t}}$, and the unemployment gap $U_{i t}-\bar{U}_{i t}$ where $\bar{Y}_{i t}$ is potential GDP and $\bar{U}_{i t}$ is the natural unemployment rate. 
To capture the persistence in the savings to GDP ratio $s_{i t}$ we allow for a dynamic specification where the savings ratio depends on its own lag $s_{i t-1}$ with $0<\alpha_{i}<1$. The dynamics of $s_{i t}$ are therefore allowed to differ from those of $b c_{i t}$ and the slope coefficient $\beta_{i}$ measures the impact of the business cycle on savings keeping the impact of past values of the business cycle variable $b c_{i t-j}($ for $j>0)$ on $s_{i t}$ constant. The total long-run impact of the business cycle on private savings is then given by $\frac{\beta_{i}}{1-\alpha_{i}}$.

Unobserved time-invariant heterogeneity is captured by the individual effect $\eta_{i}$. We also allow for heterogeneity across countries in the slope coefficients $\alpha_{i}$ and $\beta_{i}$ which reflects the fact that private savings in different countries may react differently to a given change in the business cycle, for example because financial systems, demographics, and government institutions and policies differ across countries (e.g., the generosity of welfare benefits).

The error term $\varepsilon_{i t}$ can be characterized by error cross-sectional dependence implying that it is affected by a number of unobserved common factors that affect all countries in the sample, albeit with a potentially different impact for each country, i.e., heterogeneous cross-sectional dependence. ${ }^{2}$ This reflects the fact that the private savings ratio $s_{i t}$ can be driven by for instance a common international business cycle or a common international trend in financial liberalization. It should be noted that if $\varepsilon_{i t}$ contains a international business cycle component then controlling for error cross-sectional dependence affects the interpretation of the slope coefficient $\beta_{i}$ on the business cycle indicator $b c_{i t}$. Rather than

\footnotetext{
${ }^{2}$ Model the error term $\varepsilon_{i t}$ as $\varepsilon_{i t}=\gamma_{i} f_{t}+\omega_{i t}$ where $f_{t}$ is a vector of unobserved common factors, $\gamma_{i}$ is a vector of country-specific factor loadings, and where $\omega_{i t}$ is a mean zero error term which is uncorrelated over cross sections. Allowing for country-specific factor loadings implies that cross-sectional dependence is heterogeneous and this nests homogenous cross-sectional dependence (i.e., the common time effects of time dummies where $\gamma_{i}=\gamma \forall i$ ) as a special case.
} 
measuring the total impact of $b c_{i t}$ on $s_{i t}$ we then measure the impact of the business cycle on private savings given the stance of the international business cycle. The estimation methods discussed in section 2.2 allow for cross-sectional dependence in the error term $\varepsilon_{i t}$.

Note further that the error term $\varepsilon_{i t}$ can be autocorrelated, where the autocorrelation is of the moving average form ${ }^{3}$, and it can be heteroskedastic both over time and over cross sections. The error term $\varepsilon_{i t}$ can also be correlated contemporaneously with the variable $b c_{i t}$, implying that for the coefficient $\beta_{i}$ to reflect a causal relationship going from $b c_{i t}$ to $s_{i t}$ we need to control for the endogeneity of $b c_{i t}$. The estimation methods discussed in the next section are adequate to deal with all these possibilities.

\subsection{Methodology}

Pesaran and Smith (1995) show that in a dynamic heterogeneous panel data model like in eq.(1), pooled estimators, like for instance the fixed effects estimator, in general provide inconsistent (for large $N$ and $T$ ) estimates for the average effects $\bar{\alpha}=N^{-1} \sum_{i=1}^{N} \alpha_{i}$ and $\bar{\beta}=N^{-1} \sum_{i=1}^{N} \beta_{i}$. To overcome this problem, they suggest averaging over country-bycountry coefficient estimates, i.e., $\widehat{\bar{\alpha}}=N^{-1} \sum_{i=1}^{N} \widehat{\alpha}_{i}$ and $\widehat{\bar{\beta}}=N^{-1} \sum_{i=1}^{N} \widehat{\beta}_{i}$. This yields consistent estimates for the average effects $\bar{\alpha}$ and $\bar{\beta}$ for both $N, T \rightarrow \infty$ provided that $\widehat{\alpha}_{i}$ and $\widehat{\beta}_{i}$ are consistent for $T \rightarrow \infty$. We outline four alternative estimators for the country-specific coefficients $\alpha_{i}$ and $\beta_{i}$. This will result in four alternative estimators for the average effects. Following Pesaran (2006), the asymptotic covariance matrix $\Sigma$ for

\footnotetext{
${ }^{3}$ For instance due to measurement error in the data (see Loayza et al. (2000)).
} 
each of these average estimators is consistently estimated nonparametrically ${ }^{4}$ by

$$
\widehat{\Sigma}=\frac{1}{N-1} \sum_{i=1}^{N}\left[\begin{array}{c}
\widehat{\alpha}_{i}-\widehat{\bar{\alpha}} \\
\widehat{\beta}_{i}-\widehat{\bar{\beta}}
\end{array}\right]\left[\begin{array}{ll}
\widehat{\alpha}_{i}-\widehat{\bar{\alpha}} & \widehat{\beta}_{i}-\widehat{\bar{\beta}}
\end{array}\right] .
$$

If we ignore error cross-sectional dependence, direct estimation of $\alpha_{i}$ and $\beta_{i}$ in the model in eq.(1) is possible using ordinary least squares (OLS) on eq.(1). The average over the $N$ country-specific OLS estimates is referred to as the mean group (MG) estimator. Abstracting from potential endogeneity of $b c_{i t}$ and a possible $M A$ component in $\varepsilon_{i t}$, country-by-country OLS estimation of the autoregressive model in eq.(1) yields biased but consistent (as $T \rightarrow \infty$ ) estimates for $\alpha_{i}$ and $\beta_{i}$. In this case, the MG estimator is consistent for both $N, T \rightarrow \infty$.

If $b c_{i t}$ is endogenous and/or if $\varepsilon_{i t}$ follows an $M A(q)$ process with $q>0$ the MG estimator is inconsistent. Therefore, our second estimator for $\alpha_{i}$ and $\beta_{i}$ is a GMM estimator that uses an appropriate number of periods lagged values of $s_{i t}$ and $b c_{i t}$ as instruments for $s_{i t-1}$ and $b c_{i t}$. The appropriate lag depth depends on the order $q$ of the $M A$ component in $\varepsilon_{i t}$, i.e., the first available lags are $s_{i t-1-q}$ and $b c_{i t-1-q}$. Adding deeper lags improves the efficiency of the GMM estimator. However, in order to avoid problems related to using too many instruments, we only use the first 2 available lags. This results in the instrument set $\left(s_{i t-1-q}, s_{i t-2-q}, b c_{i t-1-q}, b c_{i t-2-q}\right)$. The country-by-country GMM estimates are then averaged over the $N$ countries to obtain the MG-GMM estimator.

If we allow for error cross-sectional dependence, Pesaran (2006) shows that the cross-

\footnotetext{
${ }^{4}$ Since the standard errors are estimated using only the country-specific coefficient estimates, they are robust to the use of "generated" regressors like the cyclical variables used in this paper (e.g., the output gap ratio, the unemployment gap,...). This does not hold for the (unreported) country-specific standard errors.
} 
sectional averages of $s_{i t}, s_{i t-1}$, and $b c_{i t}$ are suitable proxies for the unobserved common factors. Country-by-country OLS estimation of the regression equation in eq.(1) augmented with the cross-sectional averages $\bar{s}_{t}, \bar{s}_{t-1}$, and $\bar{b} c_{t}$ as additional regressors gives the CCE estimator suggested by Pesaran (2006). The average over the $N$ country-specific CCE estimates is referred to as the mean group (CCEMG) estimator. Abstracting from potential endogeneity of $b c_{i t}$ and a possible $M A$ component in $\varepsilon_{i t}$, country-by-country CCE estimation of the autoregressive model in eq.(1) yields biased but consistent (as $T \rightarrow \infty)$ estimates for $\alpha_{i}$ and $\beta_{i}$. In this case, the CCEMG estimator is consistent for both $N, T \rightarrow \infty$.

If $b c_{i t}$ is endogenous and/or if $\varepsilon_{i t}$ follows an $M A(q)$ process with $q>0$ the CCEMG estimator is inconsistent. Therefore, we use GMM in the country-by-country estimation of the regression equation augmented with the cross-sectional averages $\bar{s}_{t}, \bar{s}_{t-1}$ and $\bar{b} c_{t}$. As $N \rightarrow \infty$ the cross-sectional averages $\bar{s}_{t}, \bar{s}_{t-1}$ and $\bar{b} c_{t}$ are exogenous while appropriate instruments for $s_{i t-1}$ and $b c_{i t}$ are as before $\left(s_{i t-1-q}, s_{i, t-2-q}, b c_{i t-1-q}, b c_{i t-2-q}\right)$. Also letting $T \rightarrow \infty$, this yields consistent country-by-country CCE-GMM estimates. These CCEGMM estimates are then averaged over the $N$ countries to obtain the CCEMG-GMM estimator.

\section{$2.3 \quad$ Results}

Eq.(1) is estimated using aggregate yearly data for 19 OECD countries $(N=19)$ over the period 1971-2009. The selection of countries and the sample period is determined by data availability and the aim to have as many time periods as possible for a reasonably large set of countries. More details about the countries included in the panel and about the data 
can be found in Appendix A. Table 1 reports the estimation results for each of the business cycle indicators. The reported coefficients are the average over 19 countries of the countryspecific estimates for $\alpha_{i}$ and $\beta_{i}$. As motivated in the previous subsection, the GMM estimators are constructed using $s_{i t-1-q}, s_{i t-2-q}, b c_{i t-1-q}$, and $b c_{i t-2-q}$ as instruments for the variables $s_{i t-1}$ and $b c_{i t}$. The Cumby and Huizinga (1992) autocorrelation test indicates that there is no autocorrelation in the residuals for all the estimation reported in Table 1, i.e., the order of the $M A$ component in the residuals is $q=0$ (more details can be found below). The instrument set used is therefore $\left(s_{i t-1}, s_{i, t-2}, b c_{i t-1}, b c_{i t-2}\right)$. The reported GMM estimators are two-step estimators for which the optimal weighting matrix is constructed using a White estimator allowing for heteroscedasticity.

Before discussing the specific coefficient estimates, we look at the outcomes of some diagnostic tests reported in Table $1 .{ }^{5}$ We report the average Cumby and Huizinga (1992) autocorrelation test $(\mathrm{CH})$ over 19 countries and its $p$-value. The $\mathrm{CH}$ test for residual autocorrelation is particularly suitable as it allows the model to have $M A$ errors and to be estimated by a variety of GMM estimators, including the ones used in this paper. The results show that the null of no autocorrelation cannot be rejected against the alternative of $M A(1)$ errors for any of the conducted estimations.

For the MG and MG-GMM estimators we apply the Pesaran (2004) cross-section dependence (CD) test, which tests for cross-sectional independence in the error term. In all cases the null of cross-sectional independence is rejected, suggesting that there is

\footnotetext{
${ }^{5}$ Note that, with the exception of the Pesaran (2004) cross-section dependence test, the other tests used are calculated per country and then averaged. Of these, the Hansen (1982) and the Cumby and Huizinga (1992) test statistics follow a $\chi^{2}$ distribution. Assuming that the country-specific test statistics are independent, the average Hansen (1982) and Cumby and Huizinga (1992) test still follow a $\chi^{2}$ distribution with the same number of degrees of freedom as their country-specific counterparts.
} 


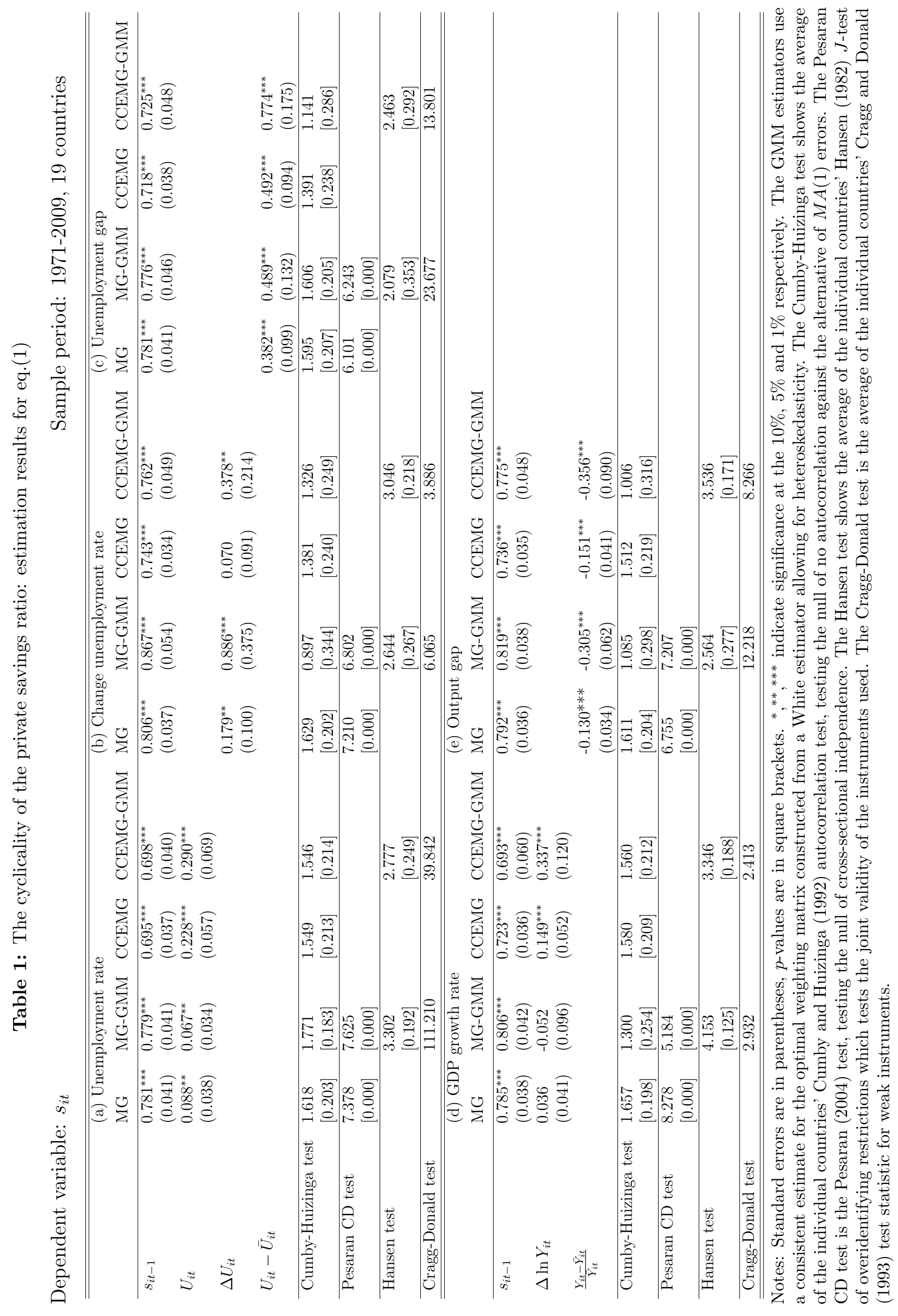


cross-sectional dependence in the error term and justifying the use of CCE estimators.

For the GMM estimators, we report the average Hansen (1982) $J$ test of overidentifying restrictions over 19 countries and its p-value. For all the conducted GMM estimations, we conclude that the moment conditions implied by the instrument sets are not rejected by the data.

The results of the Hansen $J$ test may however not be very informative when instruments are weak. To find out whether our instruments are potentially weak we use the Cragg and Donald (1993) test. ${ }^{6}$ Stock and Yogo (2004) present the critical values for this type of the test. The $5 \%$ critical value that limits the bias of the (first-step) GMM estimator to $30 \%$ of the inconsistency of the OLS estimator is about 5.5 in the case of one endogenous variable. Comparing the average Cragg-Donald test statistic reported in Table 1 for the GMM estimators with this critical value shows that we can reject the null hypothesis that the instruments are weak for 7 out of 10 GMM estimations. The instruments seem to be weak especially when the GDP growth rate is taken as a business cycle indicator.

The point estimates reported in Table 1 show that the coefficient on the lagged private savings ratio is always close to or higher than 0.7 and significant at the $1 \%$ level which implies that the private savings to GDP ratio is highly persistent.

The upper part of Table 1 shows the estimation results where unemployment-based measures serve as indicators for the business cycle. We distinguish between three mea-

\footnotetext{
${ }^{6}$ In Table 1 we report the results of estimating eq.(1) which contains only one potentially endogenous variable. In this case the Cragg-Donald statistic is identical to the F-statistic of the joint significance of the instruments in the first-stage regression. In the next section of the paper we have multiple endogenous regressors in which case the F-statistic is not informative to test the weakness of the instruments, while the Cragg-Donald test can still be used.
} 
sures; the unemployment rate $U_{i t}(\mathrm{a})$, the change in the unemployment rate $\Delta U_{i t}$ (b), and the unemployment gap $U_{i t}-\bar{U}_{i t}(\mathrm{c})$. These are countercyclical variables, i.e., they tend to increase during recessions. The estimated coefficients on any of these business cycle indicators are always positive and in most cases significant at the $1 \%$ or $5 \%$ level. ${ }^{7}$ These results imply that the private savings to GDP ratio is countercyclical, i.e., it is higher during recessions (when unemployment is relatively high).

In the lower part of Table 1 we report the estimation results obtained when using GDP-based measures for the business cycle. We use the GDP growth rate $\Delta \ln Y_{i t}$ (d) and the output gap ratio $\frac{Y_{i t}-\bar{Y}_{i t}}{Y_{i t}}(\mathrm{e})$ as indicators for the business cycle. These are procyclical variables, i.e., they tend to decrease during recessions. A countercyclical private savings ratio will therefore correspond to negative estimated coefficients for these indicators in the regression equation, eq.(1). We do find negative coefficient estimates when the estimations are conducted with the output gap as a business cycle indicator. The estimates are always significant at the $1 \%$ level. The estimated coefficients on the GDP growth rate, however, are not significant when the MG and MG-GMM estimators are used and positive and significant when the CCEMG and CCEMG-GMM estimators are used. This contrasts with the results obtained with the other business cycle measures. We provide two explanations. First, the GDP growth rate is not necessarily a good indicator of the business cycle. It also contains a long-run growth component and, as such, may be less suitable to analyze the effect of the business cycle on private savings. It should be noted that most empirical studies find a positive effect of income or GDP growth on the private savings ratio (e.g., Masson et al., 1998; Loayza et al., 2000). This

\footnotetext{
${ }^{7}$ The only exception is the CCEMG estimation of eq.(1) conducted with the change in the unemployment rate as a business cycle indicator where we find an insignificant coefficient.
} 
is often seen as direct support for the life-cycle hypothesis. Indeed, Modigliani (1970) already argued that income growth will affect private savings positively in a life-cycle setting. In a growing economy, the savings of the working population will be higher than the dissavings of retirees and therefore aggregate savings will increase. This constitutes the savings effect of permanent changes in GDP growth rates, while we are investigating the savings effect of temporary changes in GDP growth rates (i.e., the business cycle). Probably, the permanent GDP growth effect dominates the temporary GDP growth effect in the above regressions conducted with GDP growth as a business cycle indicator. Second, as explained above, the Cragg-Donald test statistic indicates that the instrument set used is weak when using real GDP growth as a business cycle meaure. This implies that we should interpret the GMM estimations conducted with the GDP growth rate with caution. Based on these objections we ignore the estimations conducted with the GDP growth rate and we conclude that there is robust evidence that the private savings ratio is countercyclical, i.e., it increases during recessions.

With the widely used output gap ratio measure $\frac{Y_{i t}-\bar{Y}_{i t}}{\bar{Y}_{i t}}$ as our preferred business cycle indicator, we find that an increase in the output gap ratio by 1 percentage point ${ }^{8}$ coincides with a decrease in the savings to GDP ratio by 0.13 percentage points (MG estimator) or 0.15 percentage points (CCEMG estimator). This effect is larger when controlling for endogeneity and reverse causality with the GMM estimators, in which case an increase in the output gap by 1 percentage point causes a decrease in the savings to GDP ratio by 0.30 percentage points (MG-GMM estimator) or 0.36 percentage points (CCEMG-GMM estimator). Note that controlling for cross-sectional dependence (which

\footnotetext{
${ }^{8}$ Over the sample period and over all countries in the sample the standard deviation of the output gap ratio equals about 2 percentage points.
} 
potentially includes cross-sectional dependence caused by common international business cycles) with the use of CCE estimators (CCEMG, CCEMG-GMM) increases the measured countercyclicality, albeit the increase is rather modest. Of course, these effects are noticeably larger in the long-run. Not controlling for endogeneity or reverse causality, the total long-run impact of an increase of the output gap ratio by 1 percentage point is a decrease of the private savings ratio by either 0.62 percentage points (MG estimator) or 0.57 percentage points (CCEMG estimator). When controlling for endogeneity or reverse causality with the GMM estimators, this total long-run impact equals 1.68 percentage points (MG-GMM estimator) or 1.58 percentage points (CCEMG-GMM estimator).

In this section we have reported robust evidence that suggests that the private savings to GDP ratio in OECD countries is countercyclical. In the remainder of the paper we provide three theoretical explanations for this result and we empirically investigate which explanation is most supported by the data.

\section{Explaining a countercyclical private savings ratio}

\subsection{Theory}

In this section we discuss three theories that unambiguously predict that the private savings ratio is countercyclical, i.e., that the private savings ratio is higher during recessions and lower during upturns.

The first theory that could explain the countercyclicality of the private savings ratio is the Ricardian Equivalence theorem (Barro, 1974). According to this theory it does not matter whether the government finances its spending through taxes or debt. The general 
idea is that if the goverment finances its deficit by issuing debt, rational agents know that this implies higher future taxes and increase their savings by exactly the amount as the rise in government debt. The theory of Ricardian equivalence has been discussed extensively in the past by the economics profession. On the one hand, it is argued that the existing evidence does not support the existence of Ricardian equivalence (see, e.g., Bernheim, 1987), while others claim that, in general, empirical work supports Ricardian equivalence (Seater, 1993). More recent studies (see, e.g., Lopez et al., 2000; de Mello et al., 2004) tend to reject full Ricardian equivalence, but find strong evidence of a partial Ricardian offset effect of private saving in response to changes in public saving. As the government savings ratio typically falls during recessions (i.e., the government deficit increases), there can therefore be a (partial) Ricardian offset by individuals in response, i.e., private savings increase relative to income. To test whether the countercyclical private savings ratio is driven by a Ricardian offset effect we use government savings expressed as a fraction of GDP as an indicator. According to the reasoning above we expect a negative coefficient for this variable; during a boom the government savings ratio is higher and the private savings ratio will be lower, and vice versa during a recession.

A second explanation for the countercyclical behavior of the private savings ratio is the existence of credit constraints. In general, liquidity constraints on households raise the saving rate (see, e.g., Jappelli and Pagano, 1994). The fact that some individuals are liquidity constrained is often used to explain why the permanent income/life cycle hypothesis is rejected by a lot of empirical studies (Jappelli and Pagano, 1989; Zeldes, 1989), but borrowing constraints can also explain the cyclicality of savings. During recessions borrowing constraints are more binding and therefore people consume less and 
save relatively more, and the opposite holds when the economy is doing well (see also Deaton (1991)). To test whether credit constraints are responsible for the countercyclical savings ratio we use the total domestic credit to the private sector expressed as a fraction of GDP as an indicator. We expect a negative sign for the coefficient on the credit ratio; a recession leads to a fall of the credit ratio, implying that the private sector faces tighter credit constraints, which leads to an increase of the private savings ratio, and vice versa during a boom.

The existence of precautionary saving motives is the third theory that can explain the countercyclical behaviour of the private savings to GDP ratio. According to this theory the private savings ratio increases when there is more (labor) income uncertainty (Leland, 1968; Caballero, 1991). Carroll (1992) argues that precautionary savings are important to understand the cyclical behavior of savings and emphasizes the role of unemployment expectations. A higher probability to become unemployed creates more uncertainty about future labor income, and in response consumers increase their target buffer-stock of saving and increase their savings. ${ }^{9}$ This implies that during periods of relatively high unemployment (i.e., recessions), the private savings ratio is higher, and vice versa in periods with relatively low unemployment (upturns). To test the precautionary savings explanation of the countercyclicality of the private savings ratio we therefore follow Carroll and Summers (1987) and Carroll (1992) by using the unemployment rate as a proxy for labor income uncertainty and we expect a positive coefficient on this variable. ${ }^{10}$

\footnotetext{
${ }^{9}$ This mechanism is also studied by Challe and Ragot (2012) who study the macroeconomic implications of time-varying precautionary saving in a general equilibrium model with unemployment risk.

${ }^{10}$ Engen and Gruber (2001) also argue that the risk of wage losses due to unemployment is a key element of future income uncertainty. They use differences in unemployment insurance among US states to test the precautionary saving hypothesis empirically and find support for this hypothesis as they find significant crowding out effects of unemployment insurance on financial asset holdings of households.
} 


\subsection{Testing the theory}

In this section we investigate which of our three alternative theoretical explanations for a countercyclical private savings ratio are supported by the data. First, in section 3.2.1, we formally test the cyclicality of the variables used to test the three theories: the government savings ratio, the private credit ratio, and the unemployment rate. Section 3.2.2 then analyses whether we can find empirical support for the theories by regressing the private savings ratio on these variables.

\subsubsection{Cyclicality governments savings ratio, credit ratio, and unemployment rate}

In the previous section we discussed how the variables used to test the theories supporting a countercyclical savings ratio can be expected to move over the business cycle. Here we check whether these expectations are confirmed in our dataset. We estimate the following regression equation for each of the variables,

$$
x_{i t}=\eta_{i}+\alpha_{i} x_{i t-1}+\beta_{i} \frac{Y_{i t}-\bar{Y}_{i t}}{\bar{Y}_{i t}}+\varepsilon_{i t} \quad i=1,2, \ldots, N, \quad t=2, \ldots, T,
$$

where $x_{i t}=\left(\frac{S_{i t}^{G}}{Y_{i t}}, \frac{C R E_{i t}}{Y_{i t}}, U_{i t}\right)$, the three variables used to test the theories that can explain our documented countercyclical private savings ratio. As mentioned in section 3.1 we use government savings $S_{i t}^{G}$ as a fraction of GDP $Y_{i t}$ to test the Ricardian offset effect, domestic credit to the private sector $C R E_{i t}$ as a fraction of GDP $Y_{i t}$ to test the importance of credit constraints, while the unemployment rate $U_{i t}$ serves as an indicator for the precautionary savings theory. We regress each of these indicators on the output put gap ratio $\frac{Y_{i t}-\bar{Y}_{i t}}{\bar{Y}_{i t}}$, our preferred measure of the business cycle. We use annual data on these variables for 19 
OECD countries $(N=19)$ over the period 1971-2009. More details on the data can be found in Appendix A. Following the reasoning of section 3.1, we expect the following signs for $\beta_{i}$ in each of the regressions: $\beta_{i}>0$ when $x_{i t}=\left(\frac{S_{i t}^{G}}{Y_{i t}}, \frac{C R E_{i t}}{Y_{i t}}\right)$ if the government savings ratio and the credit ratio are procyclical and $\beta_{i}<0$ when $x_{i t}=U_{i t}$ if the unemployment rate is countercyclical.

As in section 2.1 we estimate a dynamic specification by adding the lagged dependent variable $x_{i t-1}$ to the regression equation. And, as before, we take into account unobserved time-invariant heterogeneity through the individual effect $\eta_{i}$ and heterogeneity in the slope coefficients $\alpha_{i}$ and $\beta_{i}$. We also allow for heterogenous cross-sectional dependence, cross-section and time series heteroskedasticity in the error term $\varepsilon_{i t}$, and endogeneity of the regressor $\frac{Y_{i t}-\bar{Y}_{i t}}{\bar{Y}_{i t}}$. We use the four estimators discussed in section 2.2.

The estimation results are reported in Table 3 in Appendix D. The reported coefficients are the average over 19 countries of the country-specific estimates for $\alpha_{i}$ and $\beta_{i}$. The GMM estimators are two-step estimators for which the optimal weighting matrix is constructed using a White estimator allowing for heteroskedasticity, and are constructed using $\left(x_{i t-1}, x_{i t-2}, \frac{Y_{i t-1}-\bar{Y}_{i t-1}}{\bar{Y}_{i t-1}}, \frac{Y_{i t-2}-\bar{Y}_{i t-2}}{\bar{Y}_{i t-2}}\right)$ as an instrument set.

The estimated coefficients on the output gap always have the expected sign and are almost always significant at the $1 \%$ level. ${ }^{11}$ These results show that the government savings ratio is procyclical, i.e., it increases when the economy is doing well and falls during recessions. The effect of the business cycle on the credit ratio is also as expected; during downturns the credit ratio falls and during upturns it rises. This implies that credit constraints are more binding during recessions. And finally, the estimation results

\footnotetext{
${ }^{11}$ There is one exception when the MG-GMM estimator is used to test the cyclicality of the government savings ratio.
} 
indicate that the unemployment rate is countercyclical, i.e., it is higher in recessions and lower when there is a boom. ${ }^{12}$

After providing some basic evidence for the direction of the cyclicality of the variables used to test the three theoretical explanations for the documented countercyclical behavior of the private savings ratio, we can now investigate whether there is empirical support for these theories. This will be the subject of the next subsection.

\subsubsection{Regressing the private savings ratio on the governments savings ratio, the credit ratio, and the unemployment rate}

We first estimate a basic specification where the private savings ratio is regressed on the three variables that predict a countercyclical savings ratio: the government savings ratio, the private credit ratio, and the unemployment rate. We then discuss econometric problems that cast some doubt on the reliability of the results. Finally, we estimate an alternative specification that is not subject to the econometric problems mentioned.

\section{a) Basic specification}

We estimate the following regression equation,

$$
s_{i t}=\eta_{i}+\alpha_{i} s_{i t-1}+\beta_{i} s_{i t}^{G}+\gamma_{i} c r e_{i t}+\delta_{i} U_{i t}+\varepsilon_{i t} \quad i=1,2, \ldots, N, \quad t=2, \ldots, T,
$$

\footnotetext{
${ }^{12}$ As can be noticed from Table 3, the Cumby and Huizinga (1992) autocorrelation test often indicates that there is autocorrelation in the error terms and the Hansen (1982) $J$ test rejects the null hypothesis of the joint validity of the used instrument set in a number of cases. In principle, these problems can be solved by including MA components in the residuals and adjusting the instrument set by starting at later lags. The problem is, however, that when deeper lags are used as instruments, the Cragg and Donald (1993) test indicates that there might be a weak instruments problem. Allowing for MA errors does not alter the signs and significance of our estimated coefficients and does therefore not change our main conclusions.
} 
where $s_{i t}=\frac{S_{i t}^{P}}{Y_{i t}}$ denotes private savings $S_{i t}^{P}$ expressed as a fraction of GDP $Y_{i t}$, where $s_{i t}^{G}=\frac{S_{i t}^{G}}{Y_{i t}}$ indicates government savings $S_{i t}^{G}$ expressed as a fraction of GDP $Y_{i t}$, where cre $_{i t}=\frac{C R E_{i t}}{Y_{i t}}$ stands for domestic credit to the private sector $C R E_{i t}$ expressed as a fraction of GDP $Y_{i t}$, and where $U_{i t}$ is the unemployment rate. From our discussion in section 3.1 we expect the following signs for the estimated parameters: $\beta_{i}<0$ (Ricardian offset effect), $\gamma_{i}<0$ (credit constraints), and $\delta_{i}>0$ (precautionary savings).

Eq.(4) is estimated with data for our 19 OECD countries $(N=19)$ over the period 1971-2009. The estimation results are presented in Table 2 (left panel). The reported coefficients are the average over 19 countries of the country-specific estimates for $\alpha_{i}, \beta_{i}, \gamma_{i}$, and $\delta_{i}$. We use the MG, MG-GMM, CCEMG, and CCEMG-GMM estimators as detailed in section 2.2. As the Cumby and Huizinga (1992) autocorrelation test reported in Table 2 (left panel) indicates that there is no autocorrelation in the residuals for all the estimations reported, the instrument set used is $\left(s_{i t-1}, s_{i t-2}, s_{i t-1}^{G}, s_{i t-2}^{G}\right.$, cre $_{i t-1}$, cre $\left._{i t-2}, U_{i t-1}, U_{i t-2}\right)$.

The coefficient estimates obtained after estimating eq.(4) suggest, first, that a lower government savings ratio (i.e., a higher deficit) - which is typical for a recession - implies a higher private savings to GDP ratio (i.e., $\beta_{i}<0$ ). This is in accordance with what is predicted by the Ricardian Equivalence theorem even though the offset effect is only partial (see also e.g., Lopez et al. (2000)). The negative effect is significant at the $1 \%$ level for three of the four estimators used in the estimation. The effect is still negative when using the MG-GMM estimator, though insignificant. Since the CD test reported in Table 2 (left panel) suggests that cross-sectional dependence is an issue, we are inclined to give more weight to the results obtained with the CCEMG-GMM estimator. As such, we could conclude that the Ricardian offset effect is present and might be responsible 
for the documented countercyclicality of the private savings ratio. Second, from Table 2 (left panel) we also note that the credit ratio has a negative and significant (at the $1 \%$ level) impact on the private savings ratio irrespective of the estimator that we use (i.e., $\gamma_{i}<0$ ). This result suggests that a tightening of credit constraints faced by the private sector - something typical for a recession - which is reflected by a decrease of the credit ratio leads to an increase of the private savings ratio. We could therefore conclude that credit constraints might also be responsible for the documented countercyclicality of the private savings ratio. Third, the unemployment rate, used as a proxy for labor income uncertainty, does not have a significant positive impact on the private savings ratio. A positive and significant impact would suggest that the savings ratio is driven by precautionary motives. It does have a positive, but insignificant, impact when the GMM estimators are used. As a result, we do not find convincing evidence in support of a precautionary savings motive driving the documented countercyclicality of the private savings ratio.

These conclusions, drawn from the results obtained from estimating eq.(4), may however be misleading. There are three econometric reasons for this: weak instruments, non-stationarity issues, and omitted variables. We discuss each in turn.

\section{Weak instruments}

The estimations conducted with GMM estimators are plagued by a potential weak instruments problem. If instruments are weak, point estimates are potentially biased and inference may be unreliable. In the case of three endogenous variables the $5 \%$ critical value that limits the bias of the (first-step) GMM estimator to $30 \%$ of the inconsistency 
of the OLS estimator is about 4.5 (see Stock and Yogo (2004)). In Table 2 (left panel) we find values for the Cragg and Donald (1993) test that are below this critical value so that we cannot reject the null hypothesis that the instruments are weak.

\section{Non-stationarity}

Panel unit root tests conducted on the variables of eq.(4) reveal that we can convincingly reject the null hypothesis of a unit root in the variables $s_{i t}, s_{i t}^{G}$, and $U_{i t}$ but that we cannot reject the hypothesis of a unit root in the credit ratio cre $_{i t}$. The results of these panel unit root tests are presented in Table 4 in Appendix D. The presence of a non-stationary variable as a regressor in eq.(4) may lead to inconsistent estimation of the parameters of eq.(4) and to unreliable inference.

\section{Omitted variables}

We include in our regression only variables that imply a countercyclical private savings ratio, i.e., procyclical variables with a potentially negative impact on the savings ratio (i.e., the variables $s_{i t}^{G}$ and $c r e_{i t}$ ) or countercyclical variables with a potentially positive impact on the savings ratio (i.e., the variable $U_{i t}$ ). We do not include variables that predict a procyclical savings ratio, i.e., procyclical variables with a potentially positive impact on the private savings ratio or countercyclical variables with a potentially negative impact on the savings ratio. Variables that predict a procyclical savings ratio are real GDP growth, the inflation rate and the government transfers to GDP ratio. ${ }^{13}$ Real GDP

\footnotetext{
${ }^{13}$ The private sector wealth to GDP ratio also belongs to this category. The wealth ratio is problematic because it is a variable for which there are no good data available for all countries in the panel and, as a result, it is seldom included in private savings studies. However, the countercyclicality of the private savings ratio documented in Section 2 implies a countercyclical private wealth ratio since the change in private wealth equals private savings. Both lifecycle/permanent income and buffer stock theories of consumption further predict an unambiguously negative impact of the private wealth ratio on the private savings ratio.
} 
growth is a procyclical variable and from the life cycle/permanent income hypothesis and consumption smoothing theory we expect a positive impact on the private savings ratio. This is also what is found in the empirical literature on the determinants of the private saving rate; see e.g., Masson et al. (1998); Loayza et al. (2000). Inflation is also a procyclical variable for which in general a positive impact on the private savings ratio is expected (the macroeconomic instability argument) and found (see e.g., Loayza et al. (2000)). ${ }^{14}$ The government transfers to GDP ratio, on the other hand, is a countercyclical variable for which we expect a negative impact on the private savings ratio as government transfers can substitute for precautionary private savings; see e.g., Callen and Thimann $(1997)$

The reason for not including these variables is that the more endogenous variables we add to the regression, the larger the weak instruments problem becomes, and the harder it gets to alleviate the weak instruments problem through the use of fully robust techniques (see below). The latter techniques are based on a grid search and suffer from the curse of dimensionality, i.e., these techniques are difficult to apply when there are more than three endogenous regressors. Of course, to the extent that the included and excluded variables are correlated, our estimates may be plagued by an omitted variables bias.

Given the nature of the variables that we exclude however (i.e., variables that predict a procyclical savings ratio), the direction of the omitted variables bias should be quantifiable. Intuitively, given an overall countercyclical private savings ratio, excluding variables

\footnotetext{
${ }^{14}$ The real interest rate is another procyclical variable that is often included in private savings regressions. In general the estimated impact of the real interest rate on the private savings to GDP ratio in the literature is found to be small and insignificant (see e.g., Loayza et al. (2000)). This result probably reflects the theoretical ambiguity concerning the effect of interest rates on saving (resulting from opposing income and substitution effects).
} 
in our regression that predict a procyclical private savings ratio will underestimate the impact of the variables that predict a countercyclical savings ratio. We clarify this with an example. Suppose that the overall increase of the savings ratio in a recession is 1 percentage point. And suppose that this constitutes the net effect of an increase of 2 percentage points in the savings ratio due to an increase in the unemployment rate (included countercyclical variable that predicts a countercyclical savings ratio) and a decrease of 1 percentage point in the savings ratio due to an increase in the government transfer to GDP ratio (excluded countercyclical variable that predicts a procyclical savings ratio). By only including the former variable and not the latter, we attribute the overall increase in the savings ratio in the recession (1 percentage point) solely to the change in the unemployment rate. As such, we underestimate the true impact of the unemployment rate on the private savings ratio. In technical terms, the point estimates for the parameters on $s_{i t}^{G}$, cre $e_{i t}, U_{i t}$ in eq.(4) are in absolute value lower bounds to the true impact these variables have on the private savings ratio. In Appendix B we derive this mathematically. This lower bound result is convenient because it implies that if we find a significant impact on the private savings ratio of our included variables, then we can conclude that this constitutes convincing evidence in favour of our theories, as the true impact of these variables is probably higher than the estimated impact, but definitely not lower.

The condition for this lower bound result to hold is that covariance between the included variables and the excluded variables reflects the business cycle. This is not necessarily the case, however. In the example above we obtain a lower bound for the impact of the unemployment rate on savings (1 percentage point instead of 2 ) because - due to the recession - the excluded transfer to GDP ratio increases (and lowers the 
private savings ratio) whilst the unemployment rate increases (and augments the private savings ratio). It is however conceivable that the covariance between the included and excluded variables is not dominated by the business cycle but by other (maybe more structural) factors. Suppose for example that a structural increase in the unemployment rate decreases the generosity of the government; in order to keep the system affordable the government transfer to GDP ratio is reduced. In this case, the excluded transfer to GDP ratio decreases (and increases the private savings ratio) when the unemployment rate increases (which also increases the private savings ratio). Obviously, excluding the government transfer to GDP ratio from the regression now overstates the impact of the unemployment rate on the private savings ratio; the private savings ratio increases both because of the increase in the unemployment rate and because of the fall in the transfer to GDP ratio, but this twofold increase is attributed solely to the unemployment rate. As such, if the covariance between the included variables and the excluded variables in eq.(4) does not reflect the business cycle - as is perfectly possible -, then the lower bound result for the estimated parameters on our included regressors in eq.(4) does not hold. Hence, we do not know the direction of the omitted variables bias, and we cannot conclude anything.

Given these three econometric problems we now turn to an alternative specification where we try to tackle these problems.

\section{b) Specification with cyclical regressors}

We deal with the problems mentioned in the previous subsection by estimating a savings regression with only the cyclical components of the variables $s_{i t}^{G}, c e_{i t}$, and $U_{i t}$ included 
Table 2: Determinants countercyclical private savings ratio: estimation results eqs.(4) and (5)

Dependent variable: $s_{i t}$ Sample period: 1971-2009, 19 countries

\begin{tabular}{|c|c|c|c|c|c|c|c|c|}
\hline & \multicolumn{4}{|l|}{ Eq.(4) } & \multicolumn{4}{|l|}{ Eq.(5) } \\
\hline & MG & MG-GMM & CCEMG & CCEMG-GMM & MG & MG-GMM & CCEMG & CCEMG-GMM \\
\hline$s_{i t-1}$ & $\begin{array}{l}0.628^{* * *} \\
(0.046)\end{array}$ & $\begin{array}{l}0.643^{* * *} \\
(0.049)\end{array}$ & $\begin{array}{l}0.425^{* * *} \\
(0.054)\end{array}$ & $\begin{array}{l}0.429^{* * *} \\
(0.057)\end{array}$ & $\begin{array}{l}0.749^{* * *} \\
(0.044)\end{array}$ & $\begin{array}{l}0.750^{* * *} \\
(0.046)\end{array}$ & $\begin{array}{l}0.671^{* * *} \\
(0.042)\end{array}$ & $\begin{array}{l}0.637^{* * *} \\
(0.050)\end{array}$ \\
\hline$s_{i t}^{G}$ & $\begin{array}{l}-0.329^{* * *} \\
(0.079)\end{array}$ & $\begin{array}{l}-0.097 \\
(0.079)\end{array}$ & $\begin{array}{l}-0.537^{* * *} \\
(0.077)\end{array}$ & $\begin{array}{l}-0.351^{* * *} \\
(0.096)\end{array}$ & & & & \\
\hline cre $_{i t}$ & $\begin{array}{l}-0.014^{* * *} \\
(0.005)\end{array}$ & $\begin{array}{l}-0.013^{* * *} \\
(0.004)\end{array}$ & $\begin{array}{l}-0.032^{* * *} \\
(0.012)\end{array}$ & $\begin{array}{l}-0.024^{* * *} \\
(0.011)\end{array}$ & & & & \\
\hline$U_{i t}$ & $\begin{array}{l}-0.173^{* *} \\
(0.075)\end{array}$ & $\begin{array}{l}0.064 \\
(0.079)\end{array}$ & $\begin{array}{l}-0.049 \\
(0.142)\end{array}$ & $\begin{array}{l}0.215 \\
(0.179)\end{array}$ & & & & \\
\hline$\widetilde{s}_{i t}^{G}$ & & & & & $\begin{array}{l}-0.383^{* * *} \\
(0.059)\end{array}$ & $\begin{array}{l}-0.020 \\
(0.089)\end{array}$ & $\begin{array}{l}-0.570^{* * *} \\
(0.077)\end{array}$ & $\begin{array}{l}-0.299^{* *} \\
(0.135)\end{array}$ \\
\hline$\widetilde{c r e}_{i t}$ & & & & & $\begin{array}{l}-0.006 \\
(0.015)\end{array}$ & $\begin{array}{l}-0.002 \\
(0.025)\end{array}$ & $\begin{array}{l}-0.017 \\
(0.016)\end{array}$ & $\begin{array}{l}0.005 \\
(0.028)\end{array}$ \\
\hline$\widetilde{U}_{i t}$ & & & & & $\begin{array}{l}0.054 \\
(0.089)\end{array}$ & $\begin{array}{l}0.452^{* * *} \\
(0.139)\end{array}$ & $\begin{array}{l}0.127 \\
(0.118)\end{array}$ & $\begin{array}{l}0.474^{* * *} \\
(0.108)\end{array}$ \\
\hline Cumby-Huizinga test & $\begin{array}{l}1.621 \\
{[0.203]}\end{array}$ & $\begin{array}{l}1.290 \\
{[0.256]}\end{array}$ & $\begin{array}{l}0.987 \\
{[0.321]}\end{array}$ & $\begin{array}{l}1.300 \\
{[0.254]}\end{array}$ & $\begin{array}{l}1.179 \\
{[0.278]}\end{array}$ & $\begin{array}{l}1.153 \\
{[0.283]}\end{array}$ & $\begin{array}{l}1.199 \\
{[0.273]}\end{array}$ & $\begin{array}{l}1.389 \\
{[0.239]}\end{array}$ \\
\hline Pesaran CD test & $\begin{array}{l}8.955 \\
{[0.000]}\end{array}$ & $\begin{array}{l}8.828 \\
{[0.000]}\end{array}$ & & & $\begin{array}{l}9.036 \\
{[0.000]}\end{array}$ & $\begin{array}{l}6.175 \\
{[0.000]}\end{array}$ & & \\
\hline Hansen test & & $\begin{array}{l}5.148 \\
{[0.272]} \\
\end{array}$ & & $\begin{array}{l}5.486 \\
{[0.241]} \\
\end{array}$ & & $\begin{array}{l}5.407 \\
{[0.248]} \\
\end{array}$ & & $\begin{array}{l}6.128 \\
{[0.190]}\end{array}$ \\
\hline Cragg-Donald test & & 5.199 & & 1.889 & & 1.660 & & 0.907 \\
\hline
\end{tabular}

Notes: Standard errors are in parentheses, $p$-values are in square brackets. ${ }^{*},{ }^{* *},{ }^{* * *}$ indicate significance at the $10 \%, 5 \%$ and $1 \%$ respectively. The GMM estimators use a consistent estimate for the optimal weighting matrix constructed from a White estimator allowing for heteroskedasticity. The Cumby-Huizinga test shows the average of the individual countries' Cumby and Huizinga (1992) autocorrelation test, testing the null of no autocorrelation against the alternative of $M A(1)$ errors. The Pesaran CD test is the Pesaran (2004) test, testing the null of cross-sectional independence. The Hansen test shows the average of the individual countries' Hansen (1982) $J$-test of overidentifying restrictions which tests the joint validity of the instruments used. The Cragg-Donald test is the average of the individual countries' Cragg and Donald (1993) test statistic for weak instruments.

as regressors. Cyclical regressors contain no unit roots by definition and their correlation with the excluded variables is dominated by business cycle movements. We have calculated the correlations of the cyclical components of $s_{i t}^{G}$, cre $e_{i t}$, and $U_{i t}$ with the three excluded variables mentioned above: real GDP growth, inflation, and the government transfers to GDP ratio. We find the expected signs, e.g., the correlation between the cyclical component of $U_{i t}$ and inflation/real GDP growth is negative, the correlation between the cyclical component of $U_{i t}$ and the transfers to GDP ratio is positive, and so on... ${ }^{15}$ As a result, the direction of the omitted variables bias is known, and the estimated parameters can be considered lower bounds to the true parameters. After estimating this alternative specification, we tackle potential weak instruments problems with the use of fully robust

\footnotetext{
${ }^{15}$ Results are unreported but are available from the authors on request.
} 
techniques.

We estimate the following regression equation,

$$
s_{i t}=\eta_{i}+\alpha_{i} s_{i t-1}+\beta_{i} \widetilde{s}_{i t}^{G}+\gamma_{i} \widetilde{c r e}_{i t}+\delta_{i} \widetilde{U}_{i t}+\varepsilon_{i t} \quad i=1,2, \ldots, N, \quad t=2, \ldots, T,
$$

where $\widetilde{s}_{i t}^{G}$ is the cyclical government savings ratio, $\widetilde{c r e}_{i t}$ is cyclical credit ratio, and where $\widetilde{U}_{i t}$ is the cyclical unemployment rate which equals the unemployment gap $U_{i t}-\bar{U}_{i t}$. From our discussion in section 3.1 we expect the following signs for the estimated parameters: $\beta_{i}<0$ (Ricardian offset effect), $\gamma_{i}<0$ (credit constraints), and $\delta_{i}>0$ (precautionary savings).

For the calculation of the variables and for details on the data we refer to Appendix A. We estimate eq.(5) using yearly data for our 19 OECD countries over the period 1971-2009 using the four estimators presented in section 2.2 (i.e., the MG estimator, the MG-GMM estimator, the CCEMG estimator, and the CCEMG-GMM estimator). The estimation results are presented in Table 2 (right panel). The reported coefficients are the average over 19 countries of the country-specific estimates for $\alpha_{i}, \beta_{i}, \gamma_{i}$, and $\delta_{i}$. The instrument set is $\left(s_{i t-1}, s_{i t-2}, \widetilde{s}_{i t-1}^{G}, \widetilde{s}_{i t-2}^{G}, \widetilde{c r e}_{i t-1}, \widetilde{c r e}_{i t-2}, \widetilde{U}_{i t-1}, \widetilde{U}_{i t-2}\right)$ for the GMM estimators, since the Cumby and Huizinga (1992) autocorrelation test reported in Table 2 (right panel) indicates that autocorrelation is not an issue in our estimations.

The coefficient estimates obtained from the estimation of eq.(5) show that using cyclical components has an important impact on the results. First, whereas the credit ratio has a significant negative impact on the savings ratio, the same is not true for the cyclical credit ratio. The impact of the latter is very close to zero (in particular for the GMM 
estimators) and insignificant. This result seems to indicate that there is a structural negative impact of credit on private savings - for instance due to a relaxation of credit constraints caused by financial liberalization - but not a cyclical one. Second, contrary to the unemployment rate used in eq.(4), the cyclical unemployment rate used when estimating eq.(5) with the GMM estimators has a positive and significant impact on the private savings ratio. This result suggests that precautionary savings motives, triggered by labor income uncertainty stemming from high unemployment during recessions, can explain our documented countercyclical private savings ratio. Third, the estimated impact of the cyclical government savings ratio obtained from the estimation of eq.(5) is very similar to the estimated impact of the government savings ratio obtained from the estimation of eq.(4). This seems to indicate that the impact of government savings on private savings is strongly related to the business cycle. As such, the Ricardian offset effect is also capable of explaining our documented countercyclical private savings ratio.

The GMM estimation results however are again subject to a potential weak instruments problem. In Table 2 (right panel) we find values for the Cragg and Donald (1993) test that are below the critical value of about 4.5 reported by Stock and Yogo (2004) so that we cannot reject the null hypothesis that the instruments are weak. To check whether our results are valid despite this potential problem, we calculate confidence sets based on the Anderson-Rubin statistic (see Anderson and Rubin (1949)). This approach constitutes a fully robust method suggested by Stock et al. (2002) that does not rely on whether the instruments are strong to test hypotheses on the parameters of interest (see Kiley (2010) for an application). We construct 90\% confidence sets based on the average Anderson-Rubin statistic over 19 countries to check the significance of the two 
Figure 1: Anderson-Rubin confidence set for the impact of the cyclical unemployment rate and the cyclical government savings ratio on the private savings ratio

(a) No cross-sectional dependence

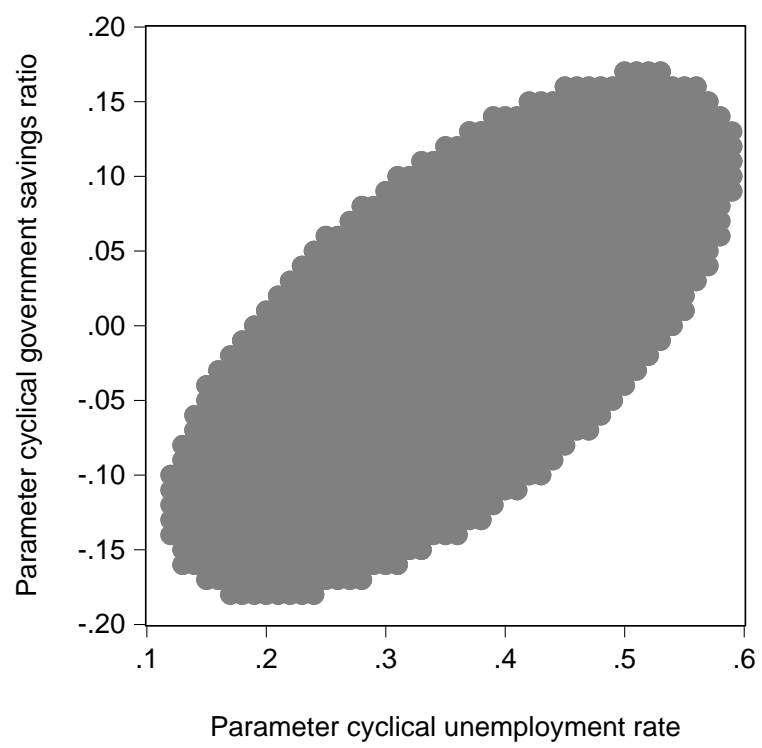

(b) Cross-sectional dependence

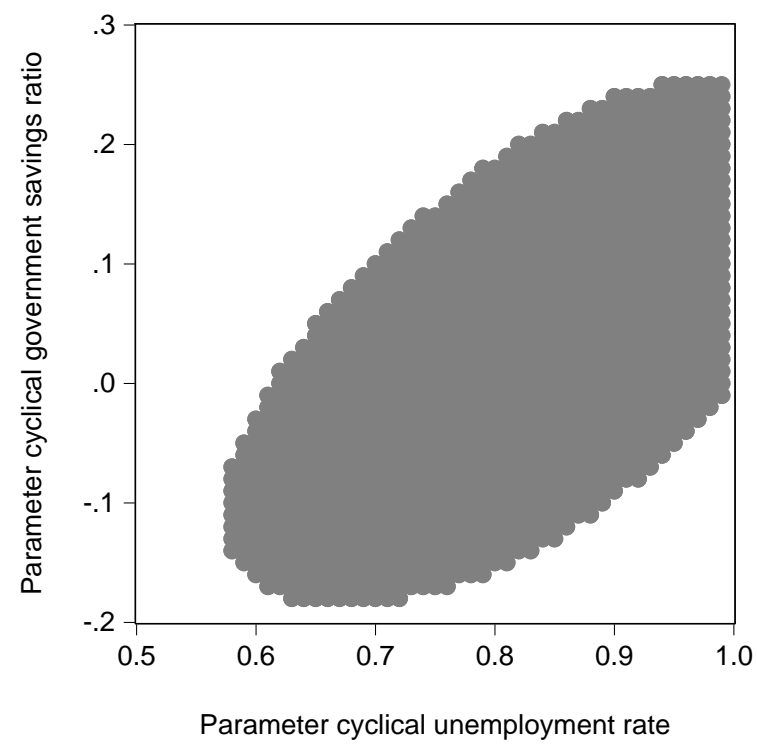

Note: $90 \%$ confidence sets are based on the average Anderson-Rubin statistic over 19 countries. Technical details are given in Appendix C.

parameters that are reported to be significant in Table 2 (right panel), i.e., the coefficient on the cyclical government savings ratio and the coefficient on the cyclical unemployment rate. Details are provided in Appendix C. In Figure 1(a) we report this confidence set for a standard regression equation of the private savings ratio on its lagged value, on the cyclical unemployment rate, and on the cyclical government savings ratio; in Figure $1(\mathrm{~b})$ we report the confidence set obtained from this regression augmented with the cross-sectional averages of the included variables to account for potential cross-sectional dependence. The instrument set used contains the same lags as the one used to conduct the GMM estimations reported in Table 2. From both figures we note that the confidence sets (shaded areas) contain the value of 0 for the parameter on the cyclical government savings ratio, but not for the parameter on the cyclical unemployment rate. As such, we are able to confirm that there is a positive and significant impact on the savings ratio 
of the cyclical unemployment rate, but we cannot confirm that there is a negative and significant effect of the cyclical government savings ratio on the private savings ratio. ${ }^{16}$

\section{Conclusions}

This paper has examined empirically how the business cycle affects the private savings to GDP ratio in a panel of 19 OECD countries over the period 1971-2009 using panel data estimation methods that take into account a large number of econometric complications (persistence in the savings ratio, endogeneity of the regressors, cross-country parameter heterogeneity, cross-sectional dependence, stationarity issues, omitted variables, and instrument strength).

An empirical analysis is called for since economic theory is ambiguous about the effects of the business cycle on the private savings ratio. On the one hand, the life cycle/permanent income theory predicts a procyclical private savings ratio. On the other hand, the theory of precautionary savings predicts a countercyclical private savings ratio.

Using both unemployment- and GDP-based business cycle measures, we have found robust evidence that the private savings ratio is countercyclical, i.e., it increases during recessions. The finding of a countercyclical private savings ratio implies two things. First, as far as business cycles are concerned, business cycle fluctuations are amplified by changes in the private savings ratio. The private savings ratio increases during a recession so that the fraction of income that is consumed decreases and this leads to a further fall in aggregate demand. Moreover, since a larger fraction of income is saved, the fiscal mul-

\footnotetext{
${ }^{16}$ Because it is known that the Anderson and Rubin (1949) statistic may have low power to reject false null hypotheses (see Stock et al. (2002)), we have also calculated confidence sets based on the Kleibergen (2002) statistic. The latter has better power properties. Those confidence sets, however, were strongly non-convex and, as such, we think that the reported Anderson and Rubin (1949) sets are more reliable.
} 
tiplier falls during a recession, which reduces the effectiveness of fiscal stimulus packages to fight the recession. Second, as far as economic growth is concerned, the increase in the private savings ratio during a recession positively affects long-run economic growth as it increases capital accumulation.

We have then empirically investigated three theories that unambiguously predict a countercyclical private savings ratio: a Ricardian offset effect, the presence of credit constraints, and the existence of a precautionary savings motive induced by labor income uncertainty. We have tested these theories by regressing the private savings ratio on the lagged private savings ratio, on the (cyclical) government savings ratio (Ricardian offset effect), on the (cyclical) private sector credit to GDP ratio (credit constraints) and on the (cyclical) unemployment rate (precautionary savings). We have found robust evidence only for a precautionary savings explanation of a countercyclical private savings ratio. 


\section{References}

Anderson, T. and Rubin, H. (1949). Estimation of the parameters of a single equation in a complete set of stochastic equations. Annals of Mathematical Statistics, 20:46-63.

Barro, R. J. (1974). Are government bonds net wealth? Journal of Political Economy, 82(6):1095-1117.

Bernheim, B. D. (1987). Ricardian equivalence: an evaluation of theory and evidence. In Fisher, S., editor, NBER Macroeconomics Annual 1987, Volume 2, pages 263-316. MIT Press, Cambridge, MA.

Bond, S., Leblebicioglu, A., and Schiantarelli, F. (2010). Capital accumulation and growth: a new look at the empirical evidence. Journal of Applied Econometrics, 25:1073-1099.

Caballero, R. J. (1991). Earnings uncertainty and aggregate wealth accumulation. American Economic Review, 81(4):859-871.

Callen, T. and Thimann, C. (1997). Empirical determinants of household saving: evidence from OECD countries. IMF Working Paper, (WP/97/181).

Carroll, C. D. (1992). The buffer-stock theory of saving: some macroeconomic evidence. Brookings Papers on Economic Activity, 1992(2):61-156.

Carroll, C. D. and Summers, L. (1987). Why have private savings rates in the United States and Canada diverged? Journal of Monetary Economics, 20:249-279.

Challe, E. and Ragot, X. (2012). Precautionary saving over the business cycle. Mimeo. 
Cragg, J. and Donald, S. (1993). Testing identifiability and specification in instrumental variables models. Econometric Theory, 9(2):222-240.

Cumby, R. E. and Huizinga, J. (1992). Testing the autocorrelation structure of disturbances in ordinary least squares and instrumental variables regressions. Econometrica, 60(1):185-195.

de Mello, L., Kongsrud, P. M., and Price, R. (2004). Savings behavior and the effectiveness of fiscal policy. OECD Working Paper, no. 397.

Deaton, A. (1991). Saving and liquidity constraints. Econometrica, 59:1221-1248.

Edwards, S. (1996). Why are Latin America's savings rates so low? An international comparative analysis. Journal of Development Economics, 51:5-44.

Engen, E. M. and Gruber, J. (2001). Unemployment insurance and precautionary saving. Journal of Monetary Economics, 47:545-579.

Everaert, G. and Pozzi, L. (2012). The predictability of aggregate consumption growth in OECD countries: a panel data analysis. Journal of Applied Econometrics, forthcoming.

Greene, W. (2003). Econometric analysis. Prentice Hall.

Hansen, L. (1982). Large sample properties of generalized method of moment estimators. Econometrica, 50:1029-1054.

Haque, N., Pesaran, M., and Sharma, S. (1999). Neglected heterogeneity and dynamics in cross-country savings regressions. IMF Working Paper, WP/99/128. 
Im, K., Pesaran, M. H., and Shin, Y. (2003). Testing for unit roots in heterogeneous panels. Journal of Econometrics, 115:53-74.

Jappelli, T. and Pagano, M. (1989). Consumption and capital market imperfections: an international comparison. American Economic Review, 79(5):1088-1105.

Jappelli, T. and Pagano, M. (1994). Saving, growth, and liquidity constraints. Quarterly Journal of Economics, 109(1):83-109.

Kiley, M. (2010). Habit persistence, nonseparability between consumption and leisure, or rule-of-thumb consumers: which accounts for the predictability of consumption growth? Review of Economics and Statistics, 92(3):679-683.

Kleibergen, F. (2002). Pivotal statistics for testing structural parameters in instrumental variables regression. Econometrica, 70(5):1781-1803.

Lane, P. and Tornell, A. (1998). Why aren't savings rates in Latin America procyclical? Journal of Development Economics, 57:185-199.

Leland, H. E. (1968). Saving and uncertainty: the precautionary demand for saving. Quarterly Journal of Economics, 82(3):465-473.

Loayza, N., Schmidt-Hebbel, K., and Servén, L. (2000). What drives private savings across the world? Review of Economics and Statistics, 82(2):165-181.

Lopez, J. H., Schmidt-Hebbel, K., and Servén, L. (2000). How effective is fiscal policy in raising national saving? Review of Economics and Statistics, 82(2):226-238. 
Masson, P. R., Bayoumi, T., and Samiei, H. (1998). International evidence on the determinants of private saving. The World Bank Economic Review, 12(3):483-501.

Modigliani, F. (1970). The life cycle hypothesis of saving and intercountry differences in the saving ratio. In Eltis, W., Scott, M., and Wolfe, J., editors, Induction, growth and trade: essays in honour of Sir Roy Harrod, pages 197-225. Clarendon, Oxford.

Pesaran, M. H. (2004). General diagnostic tests for cross section dependence in panels. IZA Discussion Paper, no. 1240.

Pesaran, M. H. (2006). Estimation and inference in large heterogeneous panels with a multifactor error structure. Econometrica, 74(4):967-1012.

Pesaran, M. H. and Smith, R. (1995). Estimating long-run relationships from dynamic heterogeneous panels. Journal of Econometrics, 68(1):79-113.

Seater, J. J. (1993). Ricardian equivalence. Journal of Economic Literature, 31(1):142190.

Stock, J. H., Wright, J. H., and Yogo, M. (2002). A survey of weak instruments and weak identification in generalized method of moments. Journal of Business \& Economic Statistics, 20(4):518-529.

Stock, J. H. and Yogo, M. (2004). Testing for weak instruments in linear IV regression. In Andrews, D. and Stock, J., editors, Identification and inference in econometric models: essays in honor of Thomas J. Rothenberg. Cambridge University Press, Cambridge, UK. 
Zeldes, S. P. (1989). Consumption and liquidity constraints: an empirical investigation. Journal of Political Economy, 97(2):305-346. 


\section{Appendices}

\section{A Data and variables}

We use annual data. Data are taken from OECD National Accounts, OECD Economic Outlook (different years), and IMF International Financial Statistics. Data availability determines the sample period which is 1971-2009. The sample contains 19 countries: Australia, Austria, Belgium, Canada, Denmark, Finland, France, Germany, Greece, Iceland, Ireland, Italy, Japan, Netherlands, Norway, Spain, Sweden, the United Kingdom, and the United States.

Nominal private savings are calculated by subtracting nominal governments savings from nominal national savings. Nominal national savings (national currency) are obtained from OECD National Accounts while nominal government savings (national currency) are obtained from OECD Economic Outlook. Nominal GDP (national currency), the GDP deflator (base year $2005=100$ ), and the unemployment rate (in \%) are taken from OECD Economic Outlook. Domestic credit to the private sector is taken from IMF International Financial Statistics (in percentage to GDP). For the latter series the missing observations at the end of the sample for Canada (the year 2009) and for Norway (the years 2007 to 2009) have been forecasted using linear extrapolation. This extrapolation is based on a regression of these countries' credit ratio on the lagged credit ratio and on the current value of the cross-country average of the credit ratio (where the cross-country average is calculated over the remaining countries in the sample).

After deflating nominal private savings, nominal government savings, and nominal GDP by the GDP deflator we obtain respectively real private savings $S_{i t}^{P}$, real government 
savings $S_{i t}^{G}$, and real GDP $Y_{i t}$. By dividing the unemployment rate (in percentage) by 100 we obtain the unemployment rate $U_{i t}$ in ratio form. By multiplying domestic credit to the private sector as a ratio to GDP by real GDP we obtain real domestic credit to the private sector $C R E_{i t}$.

The private savings ratio $s_{i t}$, the government savings ratio $s_{i t}^{G}$, and the domestic credit to the private sector ratio $\mathrm{cre}_{i t}$ are given by respectively $s_{i t}=\frac{S_{i t}^{P}}{Y_{i t}}, s_{i t}^{G}=\frac{S_{i t}^{G}}{Y_{i t}}$, and $\mathrm{cre}_{i t}=$ $\frac{C R E_{i t}}{Y_{i t}}$. The change in the unemployment rate $\Delta U_{i t}$ and real GDP growth $\Delta \ln \left(Y_{i t}\right)$ are given by respectively $\Delta U_{i t}=U_{i t}-U_{i t-1}$ and $\Delta \ln \left(Y_{i t}\right)=\ln \left(Y_{i t}\right)-\ln \left(Y_{i t-1}\right)$.

To calculate real potential GDP $\bar{Y}_{i t}$, the natural unemployment rate $\bar{U}_{i t}$, the trend in real government savings $\bar{S}_{i t}^{G}$, and the trend in domestic credit to the private sector $C \bar{R} E_{i t}$ we apply a Hodrick-Prescott filter to respectively $Y_{i t}, U_{i t}, S_{i t}^{G}$, and $C R E_{i t}$ (all with smoothing parameter equal to 100 as is standard when dealing with annual data). The cyclical components of these variables are then obtained as respectively $\tilde{Y}_{i t}=Y_{i t}-\bar{Y}_{i t}$ (i.e., the output gap), $\widetilde{U}_{i t}=U_{i t}-\bar{U}_{i t}$ (i.e., the unemployment gap), $\widetilde{S}_{i t}^{G}=S_{i t}^{G}-\bar{S}_{i t}^{G}$, and $\widetilde{C R E}_{i t}=C R E_{i t}-C \bar{R} E_{i t}$. The output gap ratio is then given by $\frac{Y_{i t}-\bar{Y}_{i t}}{\bar{Y}_{i t}}$, the cyclical government savings ratio is given by $\widetilde{S}_{i t}^{G}=\frac{\widetilde{S}_{i t}^{G}}{Y_{i t}}$, and the cyclical domestic credit ratio is given by $\widetilde{c r e}_{i t}=\frac{\widetilde{C R E}_{i t}}{\bar{Y}_{i t}}$.

\section{B Omitted variables bias and lower bound result}

\section{B.1 Theorem}

Consider the following equation for $y$,

$$
y=X_{1} \beta_{1}+X_{2} \beta_{2}+\epsilon
$$


where $X_{1}$ and $X_{2}$ are regressors with corresponding regression parameters $\beta_{1}$ and $\beta_{2}$. We assume that $\beta_{1}>0$ and $\beta_{2}>0$. This is without loss of generality as the signs of $X_{1}$ and $X_{2}$ can be adjusted to make sure these restrictions hold. If instead of the above equation we estimate

$$
y=X_{1} \beta_{1}+\eta
$$

to obtain an estimate for $\beta_{1}$, then this estimate, which we denote by $\widetilde{\beta}_{1}$, is a lower bound of the true parameter $\beta_{1}$ if and only if $\operatorname{cov}\left(X_{1}, X_{2}\right)<0$. To see this write the expectation of the estimate $\widetilde{\beta}_{1}$ conditional on both $X_{1}$ and $X_{2}$ as $E\left(\widetilde{\beta}_{1} \mid X_{1}, X_{2}\right)=\beta_{1}+\frac{\operatorname{cov}\left(X_{1}, X_{2}\right)}{V\left(X_{1}\right)} \beta_{2}$ (see e.g., Greene (2003), p. 148-149). Noting that if $\beta_{1}>0, \beta_{2}>0$, and $V\left(X_{1}\right)>0$ then $E\left(\widetilde{\beta}_{1} \mid X_{1}, X_{2}\right)<\beta_{1}$ if and only if $\operatorname{cov}\left(X_{1}, X_{2}\right)<0$

\section{B.2 Application}

Applying the theorem to our application requires three steps. First, we note that the private savings ratio $s$ equals $y$. Second, we have included variables that predict a countercyclical savings ratio $s$, namely the unemployment rate $U$ (which itself is countercyclical), the credit to GDP ratio cre (which is procyclical), and the government savings to GDP ratio $s^{G}$ (which is procyclical). We transform the latter two variables into countercyclical variables by multiplying them by -1 , i.e., - cre and $-s^{G}$. As such, the variables $U,-$ cre, and $-s^{G}$ are countercyclical variables that predict a countercyclical savings ratio $s$ implying that the impact on the savings ratio of all three variables is positive. They belong to $X_{1}$ and we have $\beta_{1}>0$. Third, we have excluded variables that predict a procyclical savings ratio $s$, namely the inflation rate, real GDP growth (which are both procyclical), and the government transfers to GDP ratio (which is countercyclical). We transform the 
latter variable into a procyclical variable by multiplying it by -1, i.e., minus government transfers to GDP. As such, the inflation rate, real GDP growth, and minus the government transfers to GDP ratio are procyclical variables that predict a procyclical savings ratio $s$ implying that the impact on the savings ratio of all three variables is positive. They belong to $X_{2}$ and we have $\beta_{2}>0$.

If the common business cycle component is the main driving force of both $X_{1}$ and $X_{2}$, then the covariance between the included countercyclical variable $X_{1}$ and the excluded procyclical variable $X_{2}$ is negative, i.e., $\operatorname{cov}\left(X_{1}, X_{2}\right)<0$ and the estimated coefficient $\widetilde{\beta}_{1}$ for the impact of the countercyclical variable on $y$ in a regression with only a countercyclical variable is a lower bound for the true impact $\beta_{1}$.

To the extent that the variables $X_{1}$ and $X_{2}$ are not driven only by a common business cycle component, the covariance between both is not necessarily dominated by the business cycle. In this case determining the sign of the covariance $\operatorname{cov}\left(X_{1}, X_{2}\right)$ and establishing the lower bound result is not possible. By calculating and using the cyclical component of $X_{1}$ instead of $X_{1}$ (see section 3.2.2b)), the business cycle component is the dominant driving process of $X_{1}$ so that a negative correlation between the cyclical component of $X_{1}$ and the excluded procyclical variable $X_{2}$ is obtained and the lower bound result holds. 


\section{Anderson-Rubin confidence sets}

\section{C.1 Anderson-Rubin statistic}

When the savings equations in the paper are estimated by GMM methods, they fit into the following general framework,

$$
\begin{aligned}
& y=X \gamma+Y \beta+\mu \\
& Y=X \phi+Z \pi+\nu
\end{aligned}
$$

The first equation denotes the estimated equation for the dependent variable. The dependent variable is denoted by the $T x 1$ vector $y$ which depends on the $T x K_{1}$ matrix of exogenous variables $X$ and on the TxM matrix of endogenous variables $Y$. The second equation is the auxiliary equation for the endogenous regressors $Y$ which depends on the $T x K_{1}$ matrix of exogenous variables $X$ and on the $T x K_{2}$ matrix of instruments $Z$. If we ignore cross-sectional dependence (e.g., when calculating the MG-GMM estimator), the matrix $X$ in our application contains a constant and the lagged dependent variable (i.e., since we find no autocorrelation in the residuals, the lagged dependent variable is exogenous). If we do not ignore cross-sectional dependence (e.g., when calculating the CCEMG-GMM estimator), the matrix $X$ in our application contains a constant, the lagged dependent variable, and the cross-sectional averages of all included variables.

After projecting out the exogenous variables $X$ from the model we obtain,

$$
\widetilde{y}=\tilde{Y} \beta+\mu
$$




$$
\widetilde{Y}=\widetilde{Z} \pi+\nu
$$

where $\widetilde{y}=M_{x} y, \widetilde{Y}=M_{x} Y$, and $\widetilde{Z}=M_{x} Z$ with $M_{x}=I-X\left(X^{\prime} X\right)^{-1} X^{\prime}$ for which we have $M_{x} X=0, M_{x} \mu=\mu$, and $M_{x} \nu=\nu$.

The Anderson-Rubin statistic (see Anderson and Rubin (1949)) measures the degree of orthogonality between the instruments $\widetilde{Z}$ and the residual $\widetilde{y}-\widetilde{Y} \beta_{0}$ calculated at the parameter vector $\beta_{0}$. It is given by,

$$
A R\left(\beta_{0}\right)=\frac{\left(\widetilde{y}-\tilde{Y} \beta_{0}\right)^{\prime} P_{\widetilde{z}}\left(\widetilde{y}-\widetilde{Y} \beta_{0}\right)}{\left(\widetilde{y}-\widetilde{Y} \beta_{0}\right)^{\prime} M_{\widetilde{z}}\left(\widetilde{y}-\widetilde{Y} \beta_{0}\right) /\left(T-K_{1}-K_{2}\right)}
$$

where $P_{\widetilde{z}}=\widetilde{Z}\left(\widetilde{Z}^{\prime} \widetilde{Z}\right)^{-1} \widetilde{Z}^{\prime}$ and where $M_{\widetilde{z}}=I-P_{\widetilde{z}}$. This statistic is asymptotically $\chi^{2}$ distributed with $K_{2}$ degrees of freedom under the null hypothesis $\beta=\beta_{0}$ (see Stock et al. (2002)). As noted by Kiley (2010) the statistic uses no information on the relationship between the instruments $\widetilde{Z}$ and the endogenous regressors $\widetilde{Y}$ and therefore does not rely on whether the instruments are strong or weak. Rather, it is based on the idea that if the true parameter vector $\beta$ is equal to the hypothesized value $\beta_{0}$ then the degree of orthogonality between the instruments $\widetilde{Z}$ and the implied error term $\mu_{0}=\widetilde{y}-\tilde{Y} \beta_{0}$ will be small. If, on the other hand, $\beta$ is far from the hypothesized value $\beta_{0}$ then the degree of orthogonality between the instruments $\widetilde{Z}$ and the implied error term $\mu_{0}$ will be large. $^{17}$

\footnotetext{
${ }^{17}$ Mathematically, if $\beta=\beta_{0}$ then $E\left[\mu_{0}^{\prime} \widetilde{Z}\right]$ will be small but if $\beta \neq \beta_{0}$ then $E\left[\mu_{0}^{\prime} \widetilde{Z}\right]$ will be large. To see this write $\mu_{0}=\widetilde{y}-\widetilde{Y} \beta_{0}=\widetilde{Y} \beta+\mu-\widetilde{Y} \beta_{0}=\widetilde{Y}\left(\beta-\beta_{0}\right)+\mu$. If $\beta=\beta_{0}$ then the instruments are orthogonal to $\mu_{0}$ because $\mu_{0}$ equals the true $\mu$ which by definition is uncorrelated with the instruments (i.e., in our case because we use lags as instruments). If $\beta \neq \beta_{0}$ then the instruments are not necessarily orthogonal to $\mu_{0}$.
} 


\section{C.2 Confidence sets}

We calculate Anderson-Rubin confidence sets as follows. We define a grid from -1 to +1 over both parameters $\beta$ and $\delta$ from eq.(5). ${ }^{18}$ We define 400 points per dimension of the two-dimensional $(\beta, \delta)$-grid. Per country we then calculate the Anderson-Rubin statistic for every point on the grid, i.e., we hypothesize all points on this grid (i.e., $400^{2}$ in total). We then average the statistics calculated for every point on the grid over 19 countries and we check whether the hypothesized points are rejected or not. ${ }^{19}$ If the $p$-value of the average Anderson-Rubin statistic for a point on the grid is larger than $10 \%$ that means that the average Anderson-Rubin statistic is relatively small at this point on the grid. This then suggests that at this point there is orthogonality between the instruments and the error term. As such, this point on the grid is close to the true $\beta$ and $\delta$. The point on the grid is then considered to belong to the $90 \%$ confidence set.

\footnotetext{
${ }^{18}$ Note that we set the coefficient $\gamma$ on the cyclical credit ratio equal to 0 based on the estimation results reported in Table 2 (right panel).

${ }^{19}$ The Anderson-Rubin test statistic follows a $\chi^{2}$ distribution. Assuming that the country-specific test statistics are independent, the average Anderson-Rubin test statistic still follows a $\chi^{2}$ distribution with the same number of degrees of freedom as its country-specific counterpart.
} 


\section{Tables}

Table 3: Cyclicality government savings ratio, credit ratio, and unemployment rate: estimation results

Sample period: $1971-2009,19$ countries

\begin{tabular}{|c|c|c|c|c|c|c|c|c|}
\hline \multirow[t]{2}{*}{ Dependent variable: } & \multicolumn{4}{|c|}{ (a) Government savings ratio } & \multicolumn{4}{|c|}{ (b) Private credit to GDP ratio } \\
\hline & MG & MG-GMM & CCEMG & CCEMG-GMM & MG & MG-GMM & CCEMG & CCEMG-GMM \\
\hline$s_{i t-1}^{G}$ & $\begin{array}{l}0.766^{* * *} \\
(0.024)\end{array}$ & $\begin{array}{l}0.788^{* * *} \\
(0.035)\end{array}$ & $\begin{array}{l}0.785^{* * *} \\
(0.040)\end{array}$ & $\begin{array}{l}0.777^{* * *} \\
(0.045)\end{array}$ & & & & \\
\hline $\operatorname{cre}_{i, t-1}$ & & & & & $\begin{array}{l}0.981^{* * *} \\
(0.034)\end{array}$ & $\begin{array}{l}1.024^{* * *} \\
(0.018)\end{array}$ & $\begin{array}{l}0.858^{* * *} \\
(0.041)\end{array}$ & $\begin{array}{l}0.879^{* * *} \\
(0.036)\end{array}$ \\
\hline$\frac{Y_{i t}-\bar{Y}_{i t}}{\bar{Y}_{i t}}$ & $\begin{array}{l}0.302^{* * *} \\
(0.043)\end{array}$ & $\begin{array}{l}0.100 \\
(0.092)\end{array}$ & $\begin{array}{l}0.205^{* * *} \\
(0.047)\end{array}$ & $\begin{array}{l}0.164^{* *} \\
(0.071)\end{array}$ & $\begin{array}{l}0.388^{* * *} \\
(0.157)\end{array}$ & $\begin{array}{l}0.452^{* * *} \\
(0.160)\end{array}$ & $\begin{array}{l}0.479^{* *} \\
(0.285)\end{array}$ & $\begin{array}{l}0.754^{* *} \\
(0.365)\end{array}$ \\
\hline Cumby-Huizinga test & $\begin{array}{l}4.074 \\
{[0.044]}\end{array}$ & $\begin{array}{l}3.276 \\
{[0.070]}\end{array}$ & $\begin{array}{l}1.738 \\
{[0.187]}\end{array}$ & $\begin{array}{l}1.442 \\
{[0.230]}\end{array}$ & $\begin{array}{l}3.406 \\
{[0.065]}\end{array}$ & $\begin{array}{l}2.723 \\
{[0.099]}\end{array}$ & $\begin{array}{l}2.599 \\
{[0.107]}\end{array}$ & $\begin{array}{l}2.432 \\
{[0.119]}\end{array}$ \\
\hline Pesaran CD test & $\begin{array}{l}28.314 \\
{[0.000]}\end{array}$ & $\begin{array}{l}27.456 \\
{[0.000]}\end{array}$ & & & $\begin{array}{l}2.869 \\
{[0.004]}\end{array}$ & $\begin{array}{l}1.858 \\
{[0.063]}\end{array}$ & & \\
\hline Hansen test & & $\begin{array}{l}6.678 \\
{[0.035]}\end{array}$ & & $\begin{array}{l}3.294 \\
{[0.193]}\end{array}$ & & $\begin{array}{l}4.328 \\
{[0.115]}\end{array}$ & & $\begin{array}{l}3.663 \\
{[0.160]}\end{array}$ \\
\hline Cragg-Donald test & & 10.005 & & 8.338 & & 14.994 & & 9.412 \\
\hline Dependent variable: & (c) Unem & ployment rat & & & & & & \\
\hline & MG & MG-GMM & CCEMG & CCEMG-GMM & & & & \\
\hline$U_{i t-1}$ & $\begin{array}{l}0.840^{* * *} \\
(0.021)\end{array}$ & $\begin{array}{l}0.828^{* * *} \\
(0.026)\end{array}$ & $\begin{array}{l}0.815^{* * *} \\
(0.030)\end{array}$ & $\begin{array}{l}0.829^{* * *} \\
(0.038)\end{array}$ & & & & \\
\hline$\frac{Y_{i t}-\bar{Y}_{i t}}{\bar{Y}_{i t}}$ & $\begin{array}{l}-0.237^{* * *} \\
(0.029)\end{array}$ & $\begin{array}{l}-0.251^{* * *} \\
(0.050)\end{array}$ & $\begin{array}{l}-0.177^{* * *} \\
(0.034)\end{array}$ & $\begin{array}{l}-0.099^{* *} \\
(0.048)\end{array}$ & & & & \\
\hline Cumby-Huizinga test & $\begin{array}{l}7.572 \\
{[0.006]}\end{array}$ & $\begin{array}{l}6.031 \\
{[0.014]}\end{array}$ & $\begin{array}{l}4.580 \\
{[0.032]}\end{array}$ & $\begin{array}{l}2.877 \\
{[0.090]}\end{array}$ & & & & \\
\hline Pesaran CD test & $\begin{array}{l}19.446 \\
{[0.000]}\end{array}$ & $\begin{array}{l}17.036 \\
{[0.000]}\end{array}$ & & & & & & \\
\hline Hansen test & & $\begin{array}{l}8.512 \\
{[0.014]}\end{array}$ & & $\begin{array}{l}5.715 \\
{[0.057]}\end{array}$ & & & & \\
\hline Cragg-Donald test & & 9.611 & & 5.867 & & & & \\
\hline
\end{tabular}

Notes: Standard errors are in parentheses, $p$-values are in square brackets. ${ }^{*},{ }^{* *},{ }^{* * *}$ indicate significance at the $10 \%, 5 \%$ and $1 \%$ respectively. The GMM estimators use a consistent estimate for the optimal weighting matrix constructed from a White estimator allowing for heteroskedasticity. The Cumby-Huizinga test shows the average of the individual countries' Cumby and Huizinga (1992) autocorrelation test, testing the null of no autocorrelation against the alternative of $M A(1)$ errors. The Pesaran CD test is the Pesaran (2004) test, testing the null of cross-sectional independence. The Hansen test shows the average of the individual countries' Hansen (1982) $J$-test of overidentifying restrictions which tests the joint validity of the instruments used. The Cragg-Donald test is the average of the individual countries' Cragg and Donald (1993) test statistic for weak instruments. 
Table 4: Im-Pesaran-Shin tests for unit roots in a heterogeneous panel Sample period: 1971-2009, 19 countries

\begin{tabular}{lllll}
\hline \hline & \multicolumn{2}{l}{ No cross-sectional dependence } & \multicolumn{2}{l}{ Cross-sectional dependence } \\
& $c$ & $c / t$ & $c$ & $c / t$ \\
\hline \multirow{3}{*}{$s_{i t}$} & -3.925 & & & -3.771 \\
\multirow{3}{*}{$s_{i t}^{G}$} & {$[0.000]$} & -5.417 & -3.625 & {$[0.000]$} \\
& -3.511 & {$[0.000]$} & {$[0.000]$} & -3.239 \\
\multirow{2}{*}{$c r e_{i t}$} & {$[0.000]$} & -2.181 & -2.933 & {$[0.001]$} \\
\multirow{2}{*}{$U_{i t}$} & 11.326 & {$[0.0146]$} & {$[0.002]$} & 1.617 \\
& {$[0.999]$} & 4.103 & 3.543 & {$[0.947]$} \\
& -2.013 & {$[0.999]$} & {$[0.999]$} & -2.935 \\
\hline \hline
\end{tabular}

Notes: The reported statistic is the $W$ test by Im et al. (2003) which follows a standard normal distribution under the null hypothesis of a unit root (against a one-sided alternative). The $p$-value is given in square brackets. The statistics calculated under the header "No cross-sectional dependence" are based on untransformed data and do not take into account potential common factors in the data. The statistics calculated under the header "Cross-sectional dependence" are based on data in deviations from the cross-sectional mean to eliminate potential common factors in the data. The $W$ statistic is based on Augmented Dickey-Fuller (ADF) tests conducted at the individual country level. The number of lags added to the individual country ADF regression is country-specific and is based on the specification that optimizes the Akaike information criterion (the maximum number of lags allowed equals 9). Columns with header " $c$ " indicate that a country-specific constant but no trend has been added to the individual country ADF regression. Columns with header " $c / t$ " indicate that a country-specific constant and a country-specific trend have been added to the individual country ADF regression. 